\title{
Effect of some climatic factors and irrigation regimes on tomato growth and chemical constituents
}

\author{
Zaki, M.S. ${ }^{1}$, F.A.AboaSedera ${ }^{1}$, L.A.Badr ${ }^{1}$, I.I.Sadek ${ }^{2}$ and A.M.El-Sawy ${ }^{2}$ \\ ${ }^{1}$ Hort.Dept.Fac.Agric., Mochtoher. Benha University \\ ${ }^{2}$ Climate Modification Departments, Central Laboratory for Agriculture Climate, Agriculture Research Center
}

\begin{abstract}
This work was performed in 2012 and 2013 seasons at El- Bostan Protected Cultivation Experimental Site, Agricultural Research Center. The aim of the study was to investigate the growth of tomato plants under various shading densities and water regimes. Tomato variety (V.T.916) F1 hybrid was used. Tomato seeds were sown on $1^{\text {st }}$ of March during both seasons of 2012 and 2013, in multi-pot transplant. Treatments used were four different levels of shade net $(73 \%, 60 \%$ and $40 \%)$ in addition to the control( without shading). Three water regimes which were tested as follow: 120\%, 100\% and 80\% from class A pan. Results indicated that the application of $73 \%$ shading was the most effective in reducing average air temperature and radiation, followed by $60 \%$, and finally $40 \%$. On the other hand, the highest values of air temperature and radiation were observed in the control treatment throughout the two growing seasons. In addition, $73 \%$ of shade density reflected the highest values of all growth aspects such as plant height, stem diameter, number of leaves and stems, fresh and dry weight of leaves and except stem diameter compared to the unshaded treatment. As for the effect of irrigation regime on vegetative growth parameters, using the highest level of irrigation water (120\% of water requirement) reflected the highest values in all determined growth parameters. With regard to the effect of the interaction between shading densities and irrigation regimes on the vegetative growth traits of tomato plants grown under sandy soil conditions. Shaded plants at $73 \%$ shade density and irrigated with the highest level of irrigation water (120\% of water requirement) exhibited the highest vegetative growth measurements except stem diameter. Moreover, shaded plants with the highest used level of shade (73\%) exhibited the highest content of total nitrogen, phosphorus, potassium and carbohydrates content compared with the medium (60\%) and low level of shading $40 \%$. In addition, the highest levels of irrigation water (120\% of water requirement) reflected the highest values of such elements. In this connection, the highest shading density (73\%) combined with the highest level of irrigation water (120\% of water requirement) led to the highest concentration of all assayed mineral macronutrients (, $\mathrm{P}$ and $\mathrm{K}$ ) or organic constituents (carbohydrates) in tomato leaves
\end{abstract}

Key words: Tomato, Shading, Water regimes, Climatic conditions, GROWTH , CHEMICAL CONSTITUENTS

\section{Introduction}

Tomato (Lycopersicon esculentum Mill.) is the most popular and widely grown vegetables in Egypt .Major producers of tomatoes include the United States, Turkey, Egypt, India and Italy where by Egypt produces 8625219 ton (FAO statistics 2012), Tomatoes are popular for their culinary properties and their health benefits. . Tomatoes and tomatobased products account for more than $85 \%$ of the dietary lycopene. Consumers demand tomatoes for many of their original characteristics. This means maintaining the color, nutritional content and level of antioxidant compounds present in the fresh fruit. These include vitamins A, C, E and carotenoids such as beta-carotene and lycopene. Irrigation is considered as one of the main agricultural practices that judge the vegetative growth of tomato plants grown either under open field or protected cultivation conditions .In this respect many investigations were carried out to study the effect of irrigation regime on vegetative growth of tomato plants. In this connection, El-Beltagy et al. (1984), Giradini et al. (1988), Fattahallah (1992), Merghaney(1997), Byari and Al Sayed(1999), Navarrete and Jeannequin(2000), all reported negative effect of water stress on tomato growth and chemical constituents of plant foliage Irrigation water is a limited agricultural resource so this study has been related to rational use water in the intensive tomato growing technology, hence the principal resource of water in Egypt is the River Nile which provide us yearly with about 55 Billion cubic meters and the second source is under ground water. Irrigation water requirements can be defined as the quantity, or depth, of irrigation water in addition to precipitation required to produce the desired crop yield and quality and to maintain an accept able salt balance in the root zone. This quantity of water must be determined for such uses as irrigation scheduling for a specific field and seasonal water needs for planning (National Engineering Handbook, 1993).

Shading has been used to limit the amount of solar radiation entering greenhouses. Shade can be 
used over the top of the greenhouse (outside) or suspended inside the greenhouse above the crop. Using shade screen improved greenhouse climate vapor pressure deficit and air temperature. This improvement implied a 36 per cent reduction of the total integral of the incident global radiation during the cropping cycle. Moreover, using shade screen during growing season contributes to increase water and radiation use efficiencies and to improve the quality of fruits (Lorenzo et al., 2003). In this regard, El-Gizawy et al. (1992), El-Abd et al.(1994), Adam et al. (2002), Abd al Mateen et al.(2007), Bushra et al.(2012), Shehata et al.(2013) studded the effect of shading density at different rates on vegetation growth of tomato plant expressed as plant height, stem diameter, number of leaves and stems, fresh and dry weight of leaves and chemical constituents of plant foliage. They found that such studded growth parameters were positively affected by shading at different level. However highest level of density in some cases reflected and reduced the effect on such parameter of growth in addition shading tomato plants in hence the absorption of micro nutrient ( $\mathrm{N}, \mathrm{P}, \mathrm{K}$ and the assimilation of carbohydrates content) Gomaa(1966), ElKassas(1985), Moustafa(1991), El-Gizawy et al. (1992), De Groot et al. (2002), Liuxian et al. (2003) Gent ( 2005), El-sayed (2009). Therefore less investigation was performed to study the effect of shading at different density and irrigation regimes as well as their interaction on growth and chemical constituents of tomato plants grown during summer season and sandy soil condition.

\section{Materials and methods}

\section{Experimental layout:}

Two field experiments were performed during the two successive summer seasons of 2012and 2013 at El- Bostan Protected Cultivation Experimental Station, Agricultural Research Center, Ministry of Agriculture and land reclamation. Location of the experimental site as follows: latitude $30^{\circ} 41 \backslash 24.9 \backslash 1$ $\mathrm{N}$, longitude $30^{\circ} 18 \backslash 06.3 \backslash \backslash \mathrm{E}$ and $29 \mathrm{~m}$ above sea level. Soil in the experimental site is sandy soil in texture with $\mathrm{pH}$ of 7.89 and Ec of $1.34 \mathrm{ds} / \mathrm{m}$.Physical and chemical analysis of soil and water are shown in Table 1.

Table 1. Average of Physical and chemical analysis of soil and water during the two seasons of study

\begin{tabular}{ccccccccccc}
\hline & \multirow{2}{*}{$\mathrm{pH}$} & \multirow{2}{*}{$\begin{array}{c}\mathrm{EC} \\
\mathrm{ds} / \mathrm{m}\end{array}$} & $\mathrm{Cl}^{-}$ & $\mathrm{HCO}_{3}{ }^{-}$ & $\mathrm{CO}_{3}{ }^{--}$ & $\mathrm{SO}_{4}^{--}$ & $\mathrm{Na}^{+}$ & $\mathrm{K}^{+}$ & $\mathrm{Ca}^{++}$ & $\mathrm{Mg}^{++}$ \\
\hline Soil & 7.89 & 1.34 & 2.5 & 2.6 & - & 43.3 & 12.2 & 1.2 & 25.0 & 10.0 \\
\hline Water & 6.5 & 0.5 & 1.6 & 2.7 & - & 0.7 & 1.6 & 0.2 & 3.0 & 0.2 \\
\hline
\end{tabular}

The current study was conducted in four single type net houses each of them $135 \mathrm{~m}^{2}$ (9m width, $15 \mathrm{~m}$ length and $3.2 \mathrm{~m}$ height) to investigate the growth and chemical composition of tomato plants grown under different levels of shading and water regimes.

\subsection{Nursery materials:}

Seeds of tomato (Lycoperscon esculentum Mill.) F1 hybrid (V.T.916) were sown on $1^{\text {st }}$ of March during both seasons of 2012 and 2013, in multi-pot transplant trays filled with mixture of peat-moss and vermiculite media $(1: 1 \mathrm{v} / \mathrm{v})$. After sowing, trays were covered by black plastic mulching for four days, then moved to high tables and were cared by irrigation, fertilization and pest management in the nursery according to the recommendation of the Ministry of Agriculture.

\subsection{Transplanting:}

After 45 days from seed sowing, transplants were set up into the net houses (on April $15^{\text {th }}$ during both seasons (2012 and 2013) on the two sides of ridges 1 $\mathrm{m}$ in width and $15 \mathrm{~m}$ in length. The distance between transplants was $50 \mathrm{~cm}$ within the row.

\subsection{The experimental treatments: \\ 1.3.1 Shading treatments:}

Three different levels of shade net was tested and compared with non-shaded house . All shading plastic net were fixed before transplanting. Used tested black shading net levels were $73 \%, 60 \%$ and $40 \%$ and compared with $0 \%$ as control.

\subsubsection{Water regime treatments}

Three water regimes were tested as follows: $120 \%, 100 \%, 80 \%$ from class A pan .

\subsubsection{Calculation of water regimes:}

Data of class A pan (Epan)for El- Bostan experimental site expressed in $\mathrm{mm} /$ day were obtained from agro meteorological station located in the site.

- The first step was calculation of potential evapotranspiration which was made according to the following formula (FAO, 1977):

$\mathrm{Et}_{\mathrm{o}}=\mathrm{K}_{\mathrm{p}}$ X E Pan (mm/day)

Where:

$\mathrm{Et}_{\mathrm{o}}=$ Potential evapotranspiration in $\mathrm{mm} /$ day.

$\mathrm{K}_{\mathrm{p}}($ Pan coefficient $)=$ three stage $(0.5,0.75 \mathrm{and} 1)$

$\mathrm{E}$ Pan $=$ Pan evaporation in $\mathrm{mm} /$ day .

The second step was to obtain values of crop water consumptive use (Etcrop) as follows (FAO, 1977).

Where:

$$
\mathrm{Et}_{\text {crop }}=\mathrm{Et}_{\mathrm{o}} \times \mathrm{Kc} \mathrm{mm} / \text { day }
$$

$\mathrm{Et}_{\mathrm{o}}=$ the rate of evapotranspiration in $\mathrm{mm}$ /day from an excessive surface of green cover of uniform height (8 to $15 \mathrm{~cm}$ ), actively growing, 
completely shading the ground and did not face shortage in water.

$\mathrm{Kc}=$ Crop coefficient "between"(0.3 to 1$)$.

The third step is to calculate water requirements (WR) for each treatment as following:

$$
\mathrm{WR}=\mathrm{Et} \text { crop } \mathrm{x} \text { L\% mm / day }
$$

Where:

$\mathrm{L} \%=$ Leaching requirement percentage in this saline as follows.

$$
\mathrm{L} \%=(\text { Eciw } / \text { Ecdw }) \times 100
$$

Where:

water $\mathrm{dS} / \mathrm{cm}-1$.

Eciw = Electrical conductivity of irrigation

Ecdw $=$ Electrical conductivity of drainage water mMho. Cm-1

$\mathrm{L} \%$ was estimated to be 1.25 .

The fourth step was to calculate irrigation requirement (IR)
As:

$\mathrm{IR}=\mathrm{WR} \times \mathrm{R}$

Where:

$\mathrm{WR}=$ water requirement

$\mathrm{R}=$ Reduction factor for drip irrigation only covers apart of land and leaves the rest dry. Therefore, it was recommend by FAO (1977) to use R-value, which its estimated range is between 0.25 and 0.9 for drip irrigation system. Finally, calculation of open field water duty (WD) was as follows:

$$
\mathrm{WD}=\mathrm{IR} \times(\text { area } / 100)
$$

\subsubsection{Amount of used water:}

Total amount of the added water through the drip irrigation system was measured by giger for each water regimes treatment.

Table 2. The amount of applied water in each treatment ( $\mathrm{m}^{3} /$ feddan) for the two seasons (2012 and 2013$)$. Period

\begin{tabular}{lccc}
\hline & $80 \%$ & $100 \%$ & $120 \%$ \\
\hline $15-30$ April & 17.24 & 21.55 & 25.86 \\
\hline 1 16-31 May & 59.13 & 73.92 & 88.70 \\
\hline 1 -15 June & 88.70 & 110.88 & 133.05 \\
\hline 16-30 June & 165.11 & 206.39 & 247.67 \\
\hline $1-15$ July & 220.15 & 275.18 & 330.22 \\
\hline $16-31$ July & 260.48 & 325.60 & 390.72 \\
\hline $1-15$ August & 325.60 & 407.00 & 488.40 \\
\hline $16-31$ August & 282.45 & 353.06 & 423.68 \\
\hline total & 251.07 & 313.83 & 376.60 \\
\hline
\end{tabular}

\subsection{Climatic conditions:}

The micro climate is a major factor in this study, thus the following data were recorded

\subsubsection{Air temperature and relative humidity:}

Average air temperatures and relative humidity of in each of the tested net-house were recorded by using digital thermo/hygrometer Art. No. 30.5000/30.5002 (Produced by TFA, Germany) placed at the middle of each plastic house the meteorological data of minimum and maximum air temperatures and relative.

\subsubsection{Light intensity:}

Average radiations in and out plastic house were measured by using Lux meter INS Dx-200, serial No. 949275

\subsection{Vegetative growth:}

Five plants were labelled from each experimental plot and the following data were recorded.

1.5.1. Plant height, number of leaves per plant and stem diameter $(10 \mathrm{~cm}$ from the soil surface) were recorded at two times after 30and 60 days from transplanting.
1.5.2. Leaf area: The leaf area of the fifth leaf from the top was recorded two times after 30 and 60 days after transplanting by using a digital leaf area meter (LI-300 Portable Area Meter Produced by LI. COR, Lincoln, Nebraska, U.S.A).

1.5.3. Arepresentative sample of three plants from each experimental unit were taken during the growth period, 180 days from transplanting to measure fresh and dry weight

\subsection{Chemical properties:}

Dry samples of plant foliage were ground and then 0.2 g.of each was digested in sulphuric and percloric acid at ratio $2: 1$ by volume and then used for determining the chemical constituents.

Nitrogen: It was determined in leaves by the distillation in a Macro-Kjeldahle apparatus ADAS/MAFF (1987).

Phosphorus: It was colorimetrically determined in leaves in the acid digest using ascorbic acid and ammonium molybdate as described by Watanabe and Olsen (1965).

Potassium: was determind flame-photometrically as described by ADAS/MAFF (1987). 


\subsection{Experimental design:}

The studied treatments were arranged using the split plot design, where, shading treatments were arranged in the main plots and water regimes treatments were arranged in the sub plots. All treatments were applied with three replicates. Randomize has been considered in the application of the studied treatment.

\subsection{Statistical analysis procedures:}

The obtained data were statistically analyzed using the analysis of variance method according to Snedecor and Cocharn (1980). Duncan's multiple range test at the $5 \%$ level of probability was used to compare means of treatments.

\section{Results and Discussion}

\section{Climatic data:}

The greatest values of average air temperatures, relative humidity and sun radiation, , were detected in the control treatment followed by $40 \%$ and $60 \%$ shading treatment as shown in (Figs. 1, 2and 3 ). However, the lowest average air temperatures, relative humidity and sun radiation were found at $73 \%$ shading. In other words, the $73 \%$ shading treatment reduced the temperature and radiation values compared to the other treatments. Results were in agreement with those reported by Hasni $\boldsymbol{e t}$ al. (2006), Coelho et al. (2006), Bartzanas and Kittas (2006) Teitel et al. (2008) ), El-Sayed (2009) , Ali (2010)and El-Sawy(2011)
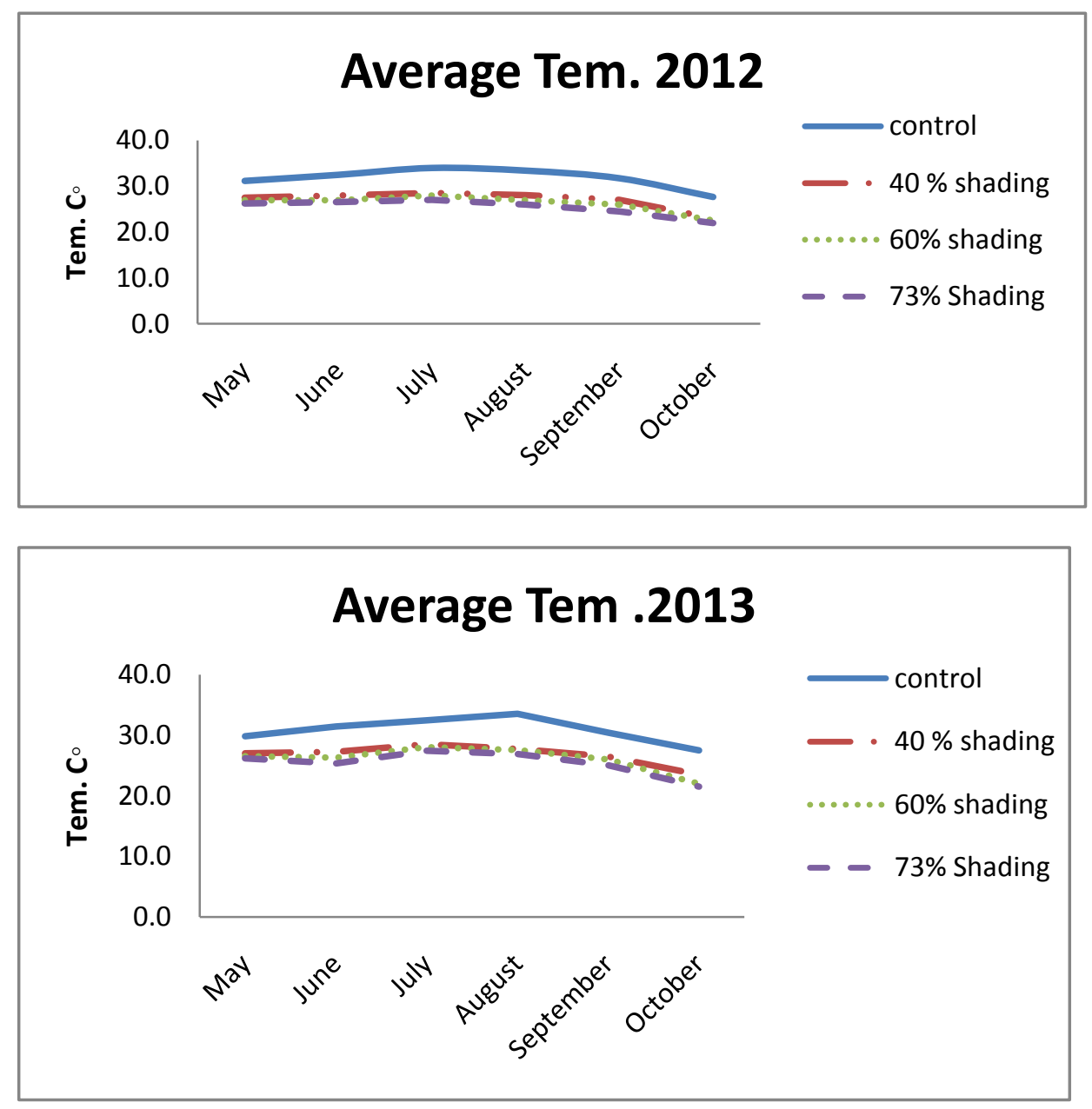

Figure (1): Effect of Shading on average air temperature at El- Bostan Protected Cultivation site during 2012 and 2013 seasons. 

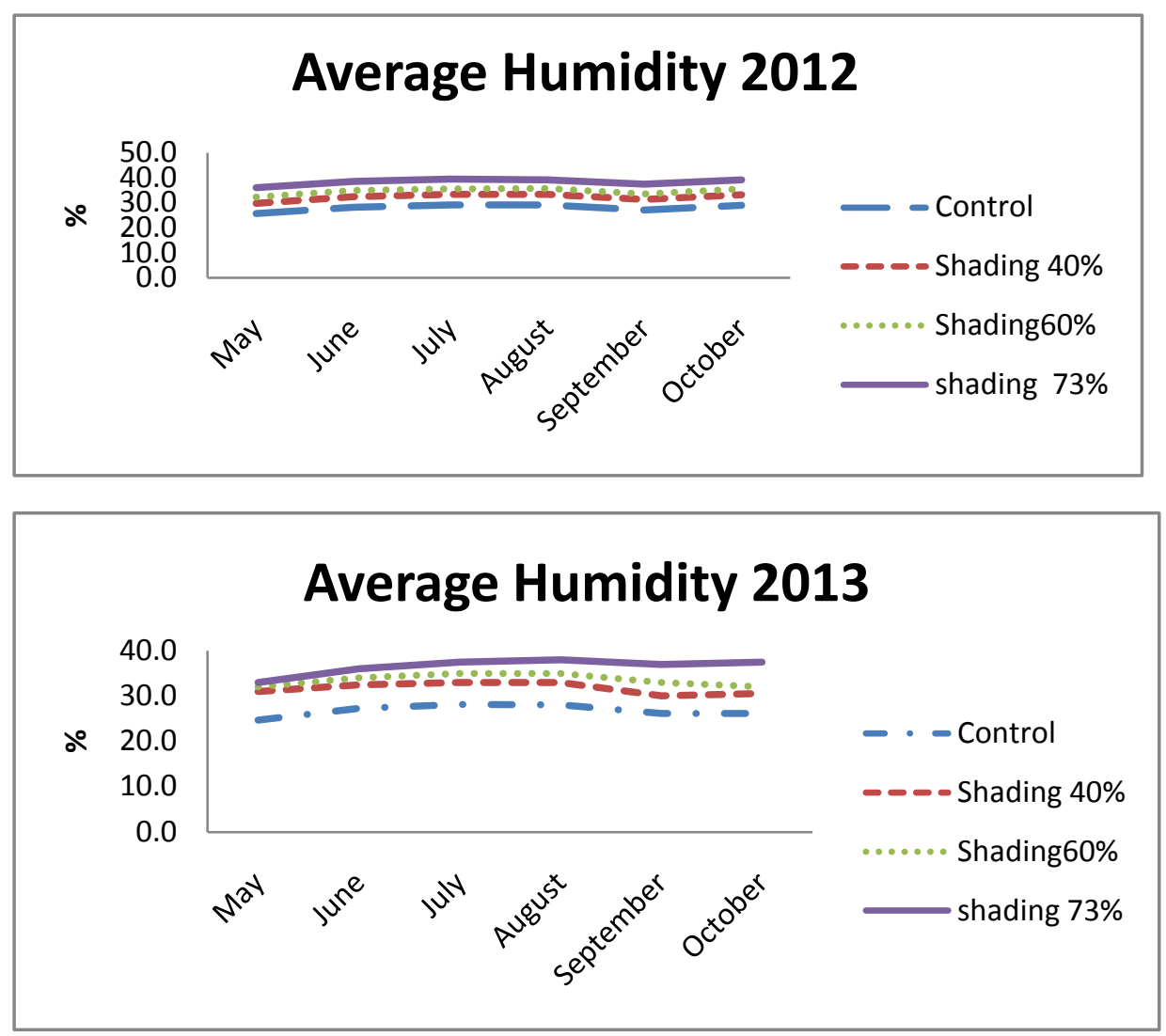

Figure (2): Effect of Shading on average relative humidity at El- Bostan Protected Cultivation site during 2012 and 2013 seasons.
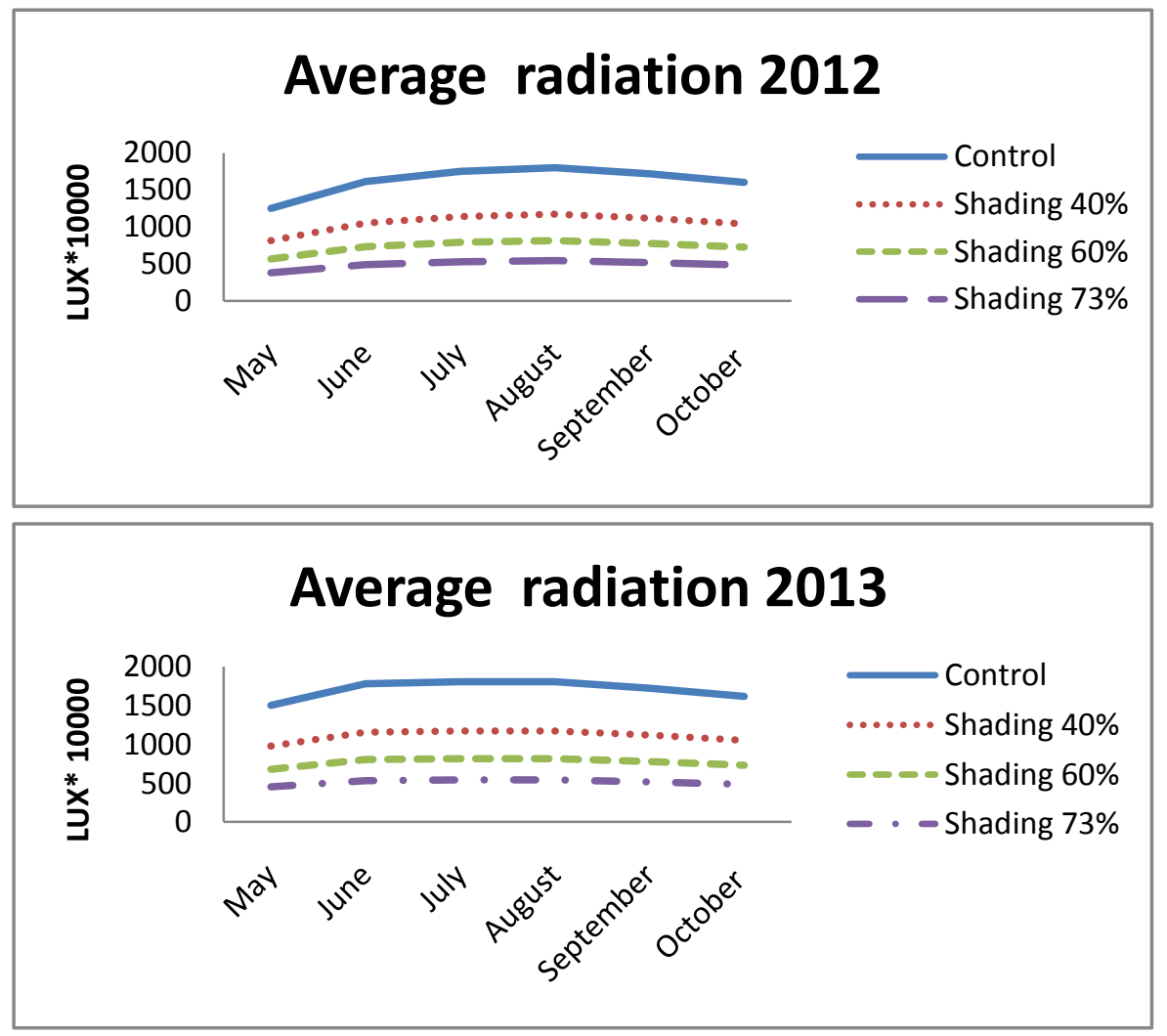

Figure (3): Effect of Shading on average sun radiation at El- Bostan Protected Cultivation site during 2012 and 2013 seasons. 


\section{Vegetative growth characteristics.}

Data presented in Tables3, 4,5and6 show the effect of shading and irrigation regimes on vegetative growth traits of tomato plants expressed as plant height, stem diameter , number of leaves and leaf area as well as fresh and dry weight of leaves, stem and total fresh and dry weight per plant during the two seasons of study.

\subsection{Effect of shading}

Data in Tables 3, 4,5and6 indicate that irrespective of plant height during both seasons after 30 days from transplanting, and number of leaves per plant after 60 days from transplanting during the first seasons only, dry weight of stem and total dry weight of plants during both seasons of study which were not significantly affected as a result of shading tomato plants with different levels of shade i-e., 40,60 and $73 \%$. In this respect, the shaded plants with $73 \%$ of shade density reflected the highest values of all growth aspects except stem diameter compared with other shaded (60 and 40\%) and the unshaded treatment. Obtained results were true during the two seasons of study. In this respect, such increments in studied morphological characters of tomato plants as a result of shading with different tested shade densities may be attributed to the decrement effect of shading on ambient temperature during the summer season under shading compared to the full sun shine and in turn decreasing the respiration rate which consequently decreased the consumption of nutrients which used in formation of new cells and tissues and consequently increased the vegetative growth.

Moreover, increasing the plant height during the two samples after 30 and 60 days from transplanting in both seasons of study may be due to the elongation of the internode to reaccept sun light radiation, but not to the increase of the number of the internodes. In this connection, El- Gizawy et al. (1992), El- Abd et al. (1994), Hamamato et al.(2000) Adam et al (2002), found that shading rates were more favorable for plant height and leaf area, but it had a decrement effect on number of leaves as well as fresh and dry weight of leaves and stems. In addition, Liu et al (2002) and Abdul Mateen et al (2007) reported that shading tomato plant with $60 \%$ of total sun light in the first case and 55 or $75 \%$ in the second case produced the maximum values for plant height, number of leaves and leaf area and total dry weight production.

\subsection{Effect of irrigation regime.}

As for the effect of irrigation regime on vegetative growth parameters data in the same Tables refer that increasing the amount of irrigation water from 80 to 100 and $120 \%$ of water requirement gradually enhanced all measured morphological aspects during both seasons of study. In this connection, such enhancing effect did not reach the level $5 \%$ of significance except in case of leaf area in both seasons and dry weight of leaves during the second season .

However, using the highest level of irrigation water $(120 \%$ of water requirement) reflected the highest values in all determined growth parameters .Obtained results are true during the two seasons of growth. Such results are in confirmety with those reported by EL- Beltagy et al .(1984), Fattahallah (1992), Merghaney (1997) Byari and Al-Sayed (1999),Navarrete and Jean nequin (2000), Ibrahim (2005) Itarmanto et al (2005), Sibomana et al (2013) all working on tomato.

\subsection{Effect of the interaction.}

With regard to the effect of the interaction between shading densities and irrigation regimes on the vegetative growth traits of tomato plants grown under sandy soil conditions, data in Tables 3, 4,5and6 indicate that there were significant differences that was found of all determined growth aspects except plant height and number of leaves in the first sample after 30 days from transplanting in the first and second season, respectively and number of leaves at the second sample (60 days from transplanting) during the first season and total dry weight per plant in the first season as well as fresh weight of leaves and dry weight of stem during the second season only. In this regard, shaded plant at $73 \%$ shade density and irrigated with the highest level of irrigation water (120\% of water requirement) exhibited the highest vegetative growth measurements except stem diameter which was higher in case of un shaded plants and irrigated with $120 \%$ of water requirement treatment of irrigation . Such results were true during both seasons of growth.

\section{Chemical composition of plant foliage.}

\subsection{Effect of shading}

Concerning the effect of shading on total nitrogen, phosphorus, potassium and carbohydrates content in plant leaves, data in Tables 7 and 8 reveal that shading at different tested rates had increasing effect on all assayed chemical, compared with unshaded plant. In this respect, such increments did not reach the level of significance in case of phosphorus during both seasons of study .In addition, shaded plants with the highest used level of shade $73 \%$ exhibited the highest content of total nitrogen phosphorus and potassium compared with the medium $60 \%$ and low level $40 \%$ of shading. Such trend was obtained in both pea was. The gradual increase of assayed macro- elements and carbohydrates with increasing shade density was connected with the increasing in vegetative growth aspects as a result of shading. Also, such gradual increasing in the concentration of macro-elements as 
a result of shading may be attributed to the decrement effect of shading on prevailing temperature during the summer season which affect and reduce respiration rate and consequently increased the vegetative and root growth which in turn increase the absorption and accumulation of such elements in plant tissues. Obtained results are in the same line with those reported by
Gomaa(1966)Moustafa(19991), El-Gizawy et al.(1992), De Groot et al. (2002), Liuxian et al.(2003) Gent (2005) and El-Sayed ( 2009 ) all working on tomato and El- Kassas(1985) working on cucumber who reported that shading the plants at different densities of shading increased the concentration of nitrogen, phosphorus and potassium in plant leaves compared with unshaded plants.

Table 3. Effect of shading levels and irrigation regimes and their interaction on vegetative growth haracteristics of tomato plants after 30 days from transplanting during the two seasons of study.

\begin{tabular}{|c|c|c|c|c|c|c|c|c|c|}
\hline \multirow{2}{*}{\multicolumn{2}{|c|}{ Treatment }} & \multicolumn{4}{|c|}{ Season (2012) } & \multicolumn{4}{|c|}{ Season (2013) } \\
\hline & & $\begin{array}{l}\text { Plant } \\
\text { height } \\
(\mathrm{cm})\end{array}$ & $\begin{array}{c}\text { Stem } \\
\text { diameter } \\
(\mathrm{cm})\end{array}$ & $\begin{array}{c}\text { No. Of } \\
\text { leaves/plant }\end{array}$ & $\begin{array}{c}\text { Leaf } \\
\text { area } \\
\left(\mathrm{cm}^{2}\right)\end{array}$ & $\begin{array}{l}\text { Plant } \\
\text { height } \\
(\mathrm{cm})\end{array}$ & $\begin{array}{c}\text { Stem } \\
\text { diameter } \\
(\mathrm{cm})\end{array}$ & $\begin{array}{c}\text { No. Of } \\
\text { leaves/plant }\end{array}$ & $\begin{array}{l}\text { Leaf area } \\
\left(\mathrm{cm}^{2}\right)\end{array}$ \\
\hline & rol & 66.3 & 1.24 & 12.5 & 69.3 & 65.7 & 1.08 & 10.5 & 53.7 \\
\hline Shad & g $40 \%$ & 78.6 & 1.14 & 15.6 & 140.7 & 71.2 & 0.94 & 11.1 & 125.7 \\
\hline Shad & $60 \%$ & 79.5 & 1.04 & 16.0 & 152.0 & 72.1 & 0.86 & 11.2 & 127.1 \\
\hline Shad & $73 \%$ & 84.5 & 0.75 & 16.2 & 173.0 & 78.0 & 0.79 & 12.7 & 156.1 \\
\hline L.S & at 0.05 & N.S & 0.47 & 2.8 & 18.4 & N.S & 0.09 & N.S & 22.1 \\
\hline $80^{\circ}$ & W.R & 71.9 & 0.97 & 13.9 & 100.2 & 68.7 & 0.80 & 10.8 & 126.9 \\
\hline 100 & W.R & 73.3 & 1.05 & 15.1 & 113.6 & 70.6 & 0.93 & 11.3 & 130.2 \\
\hline 120 & W.R & 86.3 & 1.11 & 16.2 & 133.1 & 75.9 & 1.02 & 12.1 & 144.0 \\
\hline L.S & at 0.05 & N.S & N.S & N.S & 30.4 & N.S & N.S & N.S & 26.1 \\
\hline \multirow{3}{*}{$\begin{array}{l}\overline{0} \\
\stackrel{\Xi}{0} \\
0\end{array}$} & $\begin{array}{l}80 \% \\
\text { W.R }\end{array}$ & 67.0 & 1.14 & 11.8 & 67.3 & 61.5 & 0.81 & 9.8 & 49.2 \\
\hline & $\begin{array}{l}100 \% \\
\text { W.R }\end{array}$ & 64.8 & 1.23 & 12.2 & 68.9 & 64.0 & 1.16 & 10.4 & 51.7 \\
\hline & $\begin{array}{l}120 \% \\
\text { W.R }\end{array}$ & 67.0 & 1.35 & 13.7 & 71.5 & 71.5 & 1.26 & 11.3 & 60.3 \\
\hline \multirow{3}{*}{ 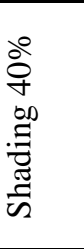 } & $\begin{array}{l}80 \% \\
\text { W.R }\end{array}$ & 71.5 & 1.05 & 14.3 & 133.3 & 69.1 & 0.85 & 10.4 & 116.0 \\
\hline & $\begin{array}{l}100 \% \\
\text { W.R } \\
\end{array}$ & 75.5 & 1.17 & 15.7 & 137.8 & 70.5 & 0.94 & 11.2 & 121.4 \\
\hline & $\begin{array}{l}120 \% \\
\text { W.R }\end{array}$ & 88.8 & 1.20 & 16.9 & 150.9 & 74.0 & 1.04 & 11.7 & 139.7 \\
\hline \multirow{3}{*}{ 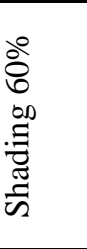 } & $\begin{array}{l}80 \% \\
\text { W.R } \\
\end{array}$ & 71.9 & 0.98 & 14.7 & 148.5 & 69.2 & 0.80 & 10.7 & 101.1 \\
\hline & $\begin{array}{l}100 \% \\
\text { W.R } \\
\end{array}$ & 75.4 & 1.04 & 16.2 & 152.5 & 71.1 & 0.85 & 11.0 & 134.1 \\
\hline & $\begin{array}{l}120 \% \\
\text { W.R }\end{array}$ & 91.2 & 1.12 & 17.1 & 154.8 & 76.1 & 0.93 & 12.1 & 146.0 \\
\hline \multirow{3}{*}{ 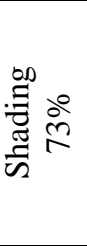 } & $\begin{array}{l}80 \% \\
\text { W.R } \\
\end{array}$ & 77.3 & 0.73 & 14.8 & 158.5 & 75.1 & 0.75 & 12.2 & 134.5 \\
\hline & $\begin{array}{l}100 \% \\
\text { W.R } \\
\end{array}$ & 77.7 & 0.76 & 16.5 & 161.7 & 76.9 & 0.77 & 12.8 & 147.2 \\
\hline & $\begin{array}{l}120 \% \\
\text { W.R }\end{array}$ & 98.4 & 0.78 & 17.2 & 198.9 & 82.0 & 0.86 & 13.2 & 186.5 \\
\hline \multicolumn{2}{|c|}{ L.S.D ${ }_{\text {at } 0.05}$} & N.S & 0.35 & 3.7 & 29.7 & 15.2 & 0.47 & N.S & 34.6 \\
\hline
\end{tabular}

\subsection{Effect of irrigation.}

With regard to the effect of irrigation regime on macro-nutrients $(\mathrm{N}, \mathrm{P}, \mathrm{K})$ and carbohydrates content in plant leaves. Data in Tables 7 and 8indicate that increasing the irrigation level from 80 to $120 \%$ of water requirement of tomato plants tended to increase the concentration of assayed macroelement, i-e., total nitrogen, phosphorus, potassium and carbohydrates in leaves. In this concept, using the highest level of irrigation water $(120 \%$ of water requirement) reflect the highest values of such elements. In addition, such increases in macroelements reached the level of significant only in case of phosphorus and potassium during the first season only while such enhancing effect in case of carbohydrate reached the level of significant during both seasons. Such enhancing effect of irrigation on determined N,P,K elements may be available for 
absorption by plant and translocate and accumulated. Obtained results are in agreement with those reported by Locasico et al. (1986), Fatia hallah (19992), Locascio and Saniastria (1996), Nahar and Gretzmacher(2002)all working on tomato. However, Ibrahim (2005) on tomato reported that increasing the amount of irrigation resulted in decreasing the concentration of $\mathrm{N}, \mathrm{P}, \mathrm{K}$ in plant leaves.

\subsection{Effect of the interaction.}

As for the effect of the interaction, the same data in Tables 7 and 8 indicate that except total nitrogen in first season and phosphorus content in second one which were not significantly affected due to the interaction treatment, using the highest shading density $(73 \%)$ combined with the highest level of irrigation water $(120 \%$ of water requirement) all assayed macro-nutrient and carbohydrate content in leaves reflected of the highest concentration

Table 4. Effect of shading levels and irrigation regimes and their interaction on vegetative growth haracteristics of tomato plants after 60 days from transplanting during the two seasons of study.

\begin{tabular}{|c|c|c|c|c|c|c|c|c|c|}
\hline \multirow{2}{*}{\multicolumn{2}{|c|}{ Treatment }} & \multicolumn{4}{|c|}{ Season (2012) } & \multicolumn{4}{|c|}{ Season (2013) } \\
\hline & & $\begin{array}{l}\text { Plant } \\
\text { height } \\
(\mathrm{cm})\end{array}$ & $\begin{array}{c}\text { Stem } \\
\text { diameter } \\
(\mathrm{cm})\end{array}$ & $\begin{array}{c}\text { Of } \\
\text { No } \\
\text {.leaves/plant }\end{array}$ & $\begin{array}{l}\text { Leaf } \\
\text { area } \\
\left(\mathrm{Cm}^{2}\right) \\
\end{array}$ & $\begin{array}{l}\text { Plant } \\
\text { height } \\
(\mathrm{cm})\end{array}$ & $\begin{array}{c}\text { Stem } \\
\text { diameter } \\
(\mathrm{cm})\end{array}$ & $\begin{array}{c}\text { No. Of } \\
\text { leaves/plant }\end{array}$ & $\begin{array}{l}\text { Leaf } \\
\text { area } \\
\left(\mathrm{Cm}^{2}\right) \\
\end{array}$ \\
\hline & trol & 145.1 & 1.31 & 20.2 & 80.2 & 134.4 & 1.24 & 17.3 & 64.9 \\
\hline & g 40\% & 158.6 & 1.26 & 22.5 & 159.9 & 147.5 & 1.05 & 21.0 & 147.8 \\
\hline & g 60\% & 163.7 & 1.15 & 21.7 & 167.6 & 152.3 & 0.96 & 20.1 & 154.0 \\
\hline & g 73\% & 176.9 & 1.24 & 22.5 & 191.1 & 162.8 & 0.94 & 18.5 & 174.1 \\
\hline & at 0.05 & 10.1 & 0.28 & N.S & 11.2 & 10.2 & 0.15 & 2.3 & 20.7 \\
\hline & W.R & 152.0 & 1.16 & 19.8 & 133.6 & 140.0 & 0.95 & 18.1 & 119.8 \\
\hline & W.R & 157.3 & 1.24 & 21.3 & 151.0 & 145.6 & 1.05 & 19.3 & 134.2 \\
\hline & W.R & 173.9 & 1.32 & 22.7 & 164.5 & 162.2 & 1.14 & 20.2 & 151.6 \\
\hline & at 0.05 & N.S & N.S & N.S & N.S & N.S & N.S & N.S & N.S \\
\hline \multirow{3}{*}{ 灾 } & $\begin{array}{l}80 \% \\
\text { W.R }\end{array}$ & 139.7 & 1.32 & 19.2 & 76.7 & 128.5 & 1.03 & 15.7 & 55.9 \\
\hline & $\begin{array}{l}100 \% \\
\text { W.R }\end{array}$ & 144.3 & 1.42 & 20.2 & 78.9 & 133.2 & 1.30 & 17.9 & 61.7 \\
\hline & $\begin{array}{c}120 \% \\
\text { W.R }\end{array}$ & 151.1 & 1.56 & 21.3 & 85.0 & 141.7 & 1.40 & 18.2 & 77.2 \\
\hline \multirow{3}{*}{ 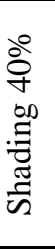 } & $\begin{array}{l}80 \% \\
\text { W.R }\end{array}$ & 150.3 & 1.24 & 18.5 & 133.8 & 138.3 & 0.96 & 17.5 & 136.8 \\
\hline & $\begin{array}{l}100 \% \\
\text { W.R } \\
\end{array}$ & 153.4 & 1.33 & 21.0 & 167.8 & 142.7 & 1.03 & 18.3 & 141.5 \\
\hline & $\begin{array}{c}120 \% \\
\text { W.R }\end{array}$ & 172.2 & 1.38 & 22.4 & 178.2 & 161.5 & 1.16 & 19.8 & 165.0 \\
\hline \multirow{3}{*}{ 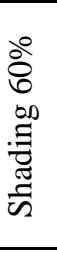 } & $\begin{array}{l}80 \% \\
\text { W.R } \\
\end{array}$ & 150.1 & 1.07 & 20.2 & 143.9 & 140.3 & 0.93 & 19.4 & 134.2 \\
\hline & $\begin{array}{l}100 \% \\
\text { W.R }\end{array}$ & 156.0 & 1.20 & 22.1 & 169.8 & 144.4 & 0.96 & 20.0 & 154.5 \\
\hline & $\begin{array}{l}120 \% \\
\text { W.R } \\
\end{array}$ & 185.0 & 1.28 & 22.7 & 189.2 & 172.2 & 1.00 & 21.1 & 173.4 \\
\hline \multirow{3}{*}{ 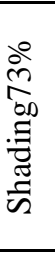 } & $\begin{array}{l}80 \% \\
\text { W.R } \\
\end{array}$ & 168.0 & 0.99 & 21.2 & 180.2 & 153.0 & 0.90 & 20.0 & 152.4 \\
\hline & $\begin{array}{l}100 \% \\
\text { W.R } \\
\end{array}$ & 175.4 & 1.00 & 22.0 & 187.4 & 161.9 & 0.93 & 21.0 & 179.0 \\
\hline & $\begin{array}{l}120 \% \\
\text { W.R }\end{array}$ & 187.2 & 1.05 & 24.3 & 205.8 & 173.3 & 1.00 & 21.8 & 190.8 \\
\hline \multicolumn{2}{|c|}{ L.S.D at 0.05} & 25.9 & 0.32 & N.S & 40.8 & 31.7 & 0.46 & 4.3 & 36.2 \\
\hline
\end{tabular}


Table 5. Effect of shading levels and irrigation regimes and their interaction on fresh and dry weight of tomato plants foliage at the end of harvesting season during the first season of growth.

\begin{tabular}{|c|c|c|c|c|c|c|c|}
\hline \multirow{2}{*}{\multicolumn{2}{|c|}{ Treatment }} & \multicolumn{6}{|c|}{ Season (2012) } \\
\hline & & $\begin{array}{c}\text { leaves fresh } \\
\text { weight } \\
(\mathrm{gm})\end{array}$ & $\begin{array}{l}\text { Leaves } \\
\text { dry } \\
\text { weight } \\
\text { (gm) }\end{array}$ & $\begin{array}{l}\text { Stem } \\
\text { Fresh } \\
\text { weight } \\
(\mathrm{gm})\end{array}$ & $\begin{array}{c}\text { Stem } \\
\text { dry } \\
\text { weight } \\
(\mathrm{gm})\end{array}$ & $\begin{array}{l}\text { Total fresh } \\
\text { weight } \\
\text { (gm) }\end{array}$ & $\begin{array}{c}\text { Total dry } \\
\text { weight } \\
\text { (gm) }\end{array}$ \\
\hline & Control & 110.1 & 19.9 & 97.0 & 20.4 & 207.1 & 40.3 \\
\hline & Shading $40 \%$ & 123.5 & 22.5 & 113.6 & 21.8 & 237.1 & 44.3 \\
\hline & Shading $60 \%$ & 134 & 24.4 & 120.8 & 22.5 & 254.8 & 46.9 \\
\hline & Shading 73\% & 147.6 & 26.5 & 128.6 & 24.2 & 276.2 & 50.7 \\
\hline & L.S.D at 0.05 & 36.9 & 5.1 & 15.1 & N.S & 32.0 & N.S \\
\hline & $80 \%$ W.R & 114.1 & 19.2 & 103.3 & 17.7 & 217.4 & 36.9 \\
\hline & $100 \%$ W.R & 130.6 & 22.3 & 118 & 21.2 & 248.6 & 43.5 \\
\hline & $120 \%$ W.R & 141.6 & 28.3 & 123.7 & 26.8 & 265.3 & 55.1 \\
\hline & L.S.D at 0.05 & N.S & N.S & N.S & N.S & N.S & N.S \\
\hline \multirow{3}{*}{$\begin{array}{l}\overline{0} \\
\stackrel{\Xi}{0} \\
0\end{array}$} & $\begin{array}{l}80 \% \\
\text { W.R }\end{array}$ & 89.21 & 17.6 & 89.8 & 15.9 & 179.01 & 33.5 \\
\hline & $\begin{array}{l}100 \% \\
\text { W.R }\end{array}$ & 112.3 & 19.8 & 96.8 & 19.3 & 209.1 & 39.1 \\
\hline & $\begin{array}{c}120 \% \\
\text { W.R }\end{array}$ & 128.9 & 22.3 & 104.4 & 25.9 & 233.3 & 48.2 \\
\hline \multirow{3}{*}{ 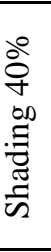 } & $\begin{array}{l}80 \% \\
\text { W.R }\end{array}$ & 117.6 & 21.5 & 99.8 & 16.3 & 217.4 & 37.8 \\
\hline & $\begin{array}{l}100 \% \\
\text { W.R }\end{array}$ & 121.6 & 24.6 & 118.9 & 20.9 & 240.5 & 45.5 \\
\hline & $\begin{array}{c}120 \% \\
\text { W.R } \\
\end{array}$ & 131.3 & 33.0 & 122 & 24.2 & 253.3 & 57.2 \\
\hline \multirow{3}{*}{ 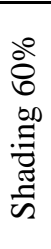 } & $\begin{array}{l}80 \% \\
\text { W.R }\end{array}$ & 125.7 & 19.0 & 104.3 & 22.2 & 230 & 41.2 \\
\hline & $\begin{array}{l}100 \% \\
\text { W.R }\end{array}$ & 132.7 & 22.8 & 125.8 & 19.5 & 258.5 & 42.3 \\
\hline & $\begin{array}{c}120 \% \\
\text { W.R }\end{array}$ & 143.7 & 31.3 & 132.4 & 26 & 276.1 & 57.3 \\
\hline \multirow{3}{*}{ 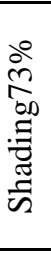 } & $\begin{array}{l}80 \% \\
\text { W.R } \\
\end{array}$ & 124.1 & 21.5 & 119.3 & 16.3 & 243.4 & 37.8 \\
\hline & $\begin{array}{l}100 \% \\
\text { W.R }\end{array}$ & 156.1 & 24.6 & 130.3 & 25.0 & 286.4 & 49.6 \\
\hline & $\begin{array}{c}120 \% \\
\text { W.R }\end{array}$ & 162.7 & 33.0 & 136 & 31.2 & 298.7 & 64.2 \\
\hline & L.S.D ${ }_{\text {at }} 0.05$ & 52.98 & 10.7 & 37.5 & 10.4 & 65.11 & N.S \\
\hline
\end{tabular}

Table 6. Effect of shading levels and irrigation regimes and their interaction on fresh and dry weight of tomato plants foliage at the end of harvesting season during the second season of growth.

\begin{tabular}{|c|c|c|c|c|c|c|}
\hline \multirow[b]{2}{*}{ Treatment } & \multicolumn{6}{|c|}{ Season (2013) } \\
\hline & $\begin{array}{c}\text { leaves } \\
\text { fresh } \\
\text { weight } \\
(\mathrm{gm})\end{array}$ & $\begin{array}{c}\text { Leaves } \\
\text { dry } \\
\text { weight } \\
\text { (gm) }\end{array}$ & $\begin{array}{c}\text { Stem } \\
\text { fresh } \\
\text { weight } \\
(\mathrm{gm})\end{array}$ & $\begin{array}{c}\text { Stem } \\
\text { dry weight } \\
(\mathrm{gm})\end{array}$ & $\begin{array}{c}\text { Total fresh } \\
\text { weight } \\
(\mathrm{gm})\end{array}$ & $\begin{array}{c}\text { Total dry } \\
\text { weight } \\
\text { (gm) }\end{array}$ \\
\hline Control & 102.3 & 17.7 & 99.48 & 23.5 & 201.78 & 41.2 \\
\hline Shading $40 \%$ & 115.7 & 20.3 & 116 & 23.5 & 231.7 & 43.8 \\
\hline Shading $60 \%$ & 126.2 & 22.2 & 123.3 & 25.6 & 249.5 & 47.8 \\
\hline Shading $73 \%$ & 139.8 & 24.3 & 131.0 & 27.3 & 270.8 & 51.6 \\
\hline L.S.D at 0.05 & 36.9 & 5.1 & 15.1 & N.S & 32.0 & N.S \\
\hline $80 \%$ W.R & 112.5 & 17.0 & 105.4 & 20.7 & 217.9 & 37.7 \\
\hline $100 \%$ W.R & 122.0 & 20.1 & 120.6 & 25.2 & 242.6 & 45.3 \\
\hline $120 \%$ W.R & 128.5 & 26.2 & 126.3 & 29.0 & 254.8 & 55.2 \\
\hline L.S.D at 0.05 & N.S & 8.9 & N.S & N.S & N.S & N.S \\
\hline
\end{tabular}




\begin{tabular}{|c|c|c|c|c|c|c|c|}
\hline \multirow{3}{*}{ 苞 } & $\begin{array}{l}80 \% \\
\text { W.R }\end{array}$ & 87.6 & 15.4 & 91.9 & 19.0 & 179.5 & 34.4 \\
\hline & $\begin{array}{l}100 \% \\
\text { W.R }\end{array}$ & 103.6 & 17.6 & 99.5 & 23.4 & 203.1 & 41 \\
\hline & $120 \%$ W.R & 115.8 & 20.1 & 107.0 & 28.1 & 222.8 & 48.2 \\
\hline \multirow{3}{*}{ 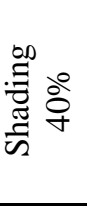 } & $\begin{array}{l}80 \% \\
\text { W.R }\end{array}$ & 115.9 & 16.6 & 106.4 & 19.4 & 222.3 & 36 \\
\hline & $\begin{array}{l}100 \% \\
\text { W.R }\end{array}$ & 112.9 & 20 & 128.4 & 24.9 & 241.3 & 44.9 \\
\hline & $120 \%$ W.R & 118.1 & 24.3 & 135.0 & 26.3 & 253.1 & 50.6 \\
\hline \multirow{3}{*}{ 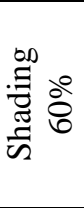 } & $\begin{array}{l}80 \% \\
\text { W.R }\end{array}$ & 124.0 & 16.8 & 102.0 & 25.2 & 226 & 42 \\
\hline & $\begin{array}{l}100 \% \\
\text { W.R }\end{array}$ & 124.0 & 20.6 & 121.6 & 23.5 & 245.6 & 44.1 \\
\hline & $120 \%$ W.R & 130.5 & 29.1 & 124.6 & 28.1 & 255.1 & 57.2 \\
\hline \multirow{4}{*}{ 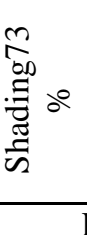 } & $\begin{array}{l}80 \% \\
\text { W.R }\end{array}$ & 122.4 & 19.3 & 121.4 & 19.4 & 243.8 & 38.7 \\
\hline & $\begin{array}{l}100 \% \\
\text { W.R }\end{array}$ & 147.4 & 22.4 & 133.0 & 29.1 & 280.4 & 51.5 \\
\hline & $120 \%$ W.R & 149.6 & 31.2 & 138.6 & 33.4 & 288.2 & 64.6 \\
\hline & $\mathrm{D}_{\text {at } 0.05}$ & N.S & 10.2 & 37.5 & N.S & 66.4 & 21.2 \\
\hline
\end{tabular}

Table 7: Effect of shading levels and irrigation regimes and their interaction on total nitrogen , phosphorus , potassium $(\mathrm{mg} / 100 \mathrm{gm})$ and carbohydrate \%content of leaves at the end of harvesting season during the first seasons of growth.

\begin{tabular}{|c|c|c|c|c|c|}
\hline \multicolumn{6}{|c|}{ Season (2012) } \\
\hline \multicolumn{2}{|c|}{ Treatment } & $\mathrm{N}$ & $\mathrm{P}$ & $\mathrm{K}$ & Total carbohydrates \\
\hline \multicolumn{2}{|c|}{ Control } & 1328.0 & 145.6 & 1724.0 & 9.64 \\
\hline \multicolumn{2}{|c|}{ Shading $40 \%$} & 1392.0 & 175.6 & 2286.0 & 11.59 \\
\hline \multicolumn{2}{|c|}{ Shading $60 \%$} & 1504.0 & 184.4 & 2567.0 & 11.97 \\
\hline \multicolumn{2}{|c|}{ Shading $73 \%$} & 1712.0 & 198.9 & 2911.0 & 12.72 \\
\hline \multicolumn{2}{|c|}{ L.S.D at 0.05} & 67.1 & N.S & 907.6 & 0.89 \\
\hline \multicolumn{2}{|c|}{$80 \%$ W.R } & 1413 & 134.2 & 1707 & 10.32 \\
\hline \multicolumn{2}{|c|}{$100 \%$ W.R } & 1467 & 163.3 & 2172 & 11.28 \\
\hline \multicolumn{2}{|c|}{$120 \%$ W.R } & 1592 & 230.8 & 3236 & 12.84 \\
\hline \multicolumn{2}{|c|}{ L.S.D ${ }_{\text {at } 0.05}$} & N.S & 96.2 & 1263 & 1.50 \\
\hline \multirow{3}{*}{$\begin{array}{l}\overline{0} \\
\stackrel{0}{0} \\
0\end{array}$} & $80 \%$ W.R & 1190 & 1067.0 & 1207 & 8.60 \\
\hline & $\begin{array}{l}100 \% \\
\text { W.R }\end{array}$ & 1257 & 1367.0 & 1590 & 9.80 \\
\hline & $120 \%$ W.R & 1290 & 1933.0 & 2377 & 10.53 \\
\hline \multirow{3}{*}{ 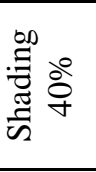 } & $80 \%$ W.R & 1347 & 140.0 & 1723 & 10.47 \\
\hline & $\begin{array}{l}100 \% \\
\text { W.R }\end{array}$ & 1363 & 163.3 & 2400 & 11.30 \\
\hline & $120 \%$ W.R & 1450 & 223.3 & 2733 & 13.00 \\
\hline \multirow{3}{*}{ 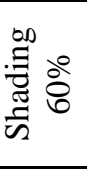 } & $80 \%$ W.R & 1437 & 140.0 & 1733 & 10.80 \\
\hline & $\begin{array}{l}100 \% \\
\text { W.R } \\
\end{array}$ & 1500 & 173.3 & 2267 & 11.73 \\
\hline & $120 \%$ W.R & 1650 & 240.0 & 3700 & 13.37 \\
\hline \multirow{3}{*}{ 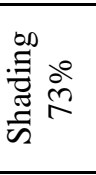 } & $80 \%$ W.R & 1677 & 150.0 & 2167 & 11.40 \\
\hline & $\begin{array}{c}100 \% \\
\text { W.R }\end{array}$ & 1750 & 180.0 & 2433 & 12.30 \\
\hline & $120 \%$ W.R & 1980 & 266.7 & 4133 & 14.47 \\
\hline \multicolumn{2}{|c|}{ L.S.D ${ }_{\text {at } 0.05}$} & N.S & 109.4 & 1437 & 1.70 \\
\hline
\end{tabular}


Table 8. Effect of shading levels and irrigation regimes and their interaction on total nitrogen, phosphorus , potassium(mg/100mg) and carbohydrates \%content of leaves at the end of harvesting season during the second seasons of growth.

\begin{tabular}{|c|c|c|c|c|c|}
\hline \multicolumn{6}{|c|}{ Season (2013) } \\
\hline \multicolumn{2}{|c|}{ Treatment } & $\mathrm{N}$ & $\mathrm{P}$ & $\mathrm{K}$ & Total carbohydrates \\
\hline \multicolumn{2}{|c|}{ Control } & 1412 & 1500 & 1792 & 10.13 \\
\hline \multicolumn{2}{|c|}{ Shading $40 \%$} & 1380 & 1722 & 2300 & 12.18 \\
\hline \multicolumn{2}{|c|}{ Shading $60 \%$} & 1540 & 1778 & 2811 & 12.60 \\
\hline \multicolumn{2}{|c|}{ Shading $73 \%$} & 1720 & 1889 & 2889 & 13.40 \\
\hline \multicolumn{2}{|c|}{ L.S.D at 0.05} & 70 & N.S & 891.3 & 0.99 \\
\hline \multicolumn{2}{|c|}{$80 \%$ W.R } & 1439 & 1392 & 1967 & 10.85 \\
\hline \multicolumn{2}{|c|}{$100 \%$ W.R } & 1453 & 1633 & 2294 & 11.73 \\
\hline \multicolumn{2}{|c|}{$120 \%$ W.R } & 1560 & 2142 & 3083 & 13.65 \\
\hline \multicolumn{2}{|c|}{ L.S.D ${ }_{\text {at } 0.05}$} & N.S & N.S & N.S & 2.65 \\
\hline \multirow{5}{*}{$\begin{array}{l}\overline{0} \\
\stackrel{0}{0} \\
ن\end{array}$} & $80 \%$ & 1450 & 123.3 & 1433 & 9.03 \\
\hline & W.R & & & & \\
\hline & $100 \%$ & 1250 & 143.3 & 1577 & 10.20 \\
\hline & W.R & & & & \\
\hline & $120 \%$ W.R & 1283 & 183.3 & 2367 & 11.17 \\
\hline \multirow{5}{*}{ 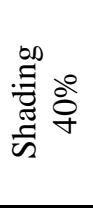 } & $80 \%$ & 1340 & 136.7 & 1667 & 11.00 \\
\hline & W.R & & & & \\
\hline & $100 \%$ & 1380 & 170.0 & 2533 & 11.73 \\
\hline & W.R & & & & \\
\hline & $120 \%$ W.R & 1457 & 210.0 & 2700 & 13.80 \\
\hline \multirow{5}{*}{ 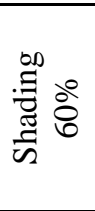 } & $80 \%$ & 1380 & 140.0 & 2467 & 11.37 \\
\hline & W.R & & & & \\
\hline & $100 \%$ & 1483 & 170.0 & 2467 & 12.20 \\
\hline & W.R & & & & \\
\hline & $120 \%$ W.R & 1650 & 223.3 & 3500 & 14.23 \\
\hline \multirow{5}{*}{ 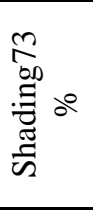 } & $80 \%$ & 1587 & 156.7 & 2300 & 12.00 \\
\hline & W.R & & & & \\
\hline & $100 \%$ & 1700 & 170.0 & 2600 & 12.80 \\
\hline & W.R & & & & \\
\hline & $120 \%$ W.R & 1850 & 240.0 & 3767 & 15.40 \\
\hline \multicolumn{2}{|c|}{ L.S.D at 0.05} & 253 & N.S & 1370 & 3.01 \\
\hline
\end{tabular}

\section{Conclusion}

It can be concluded that, using shade screen net $73 \%$ enhance all morphological aspects of tomato plants grown at summer seasons, in addition ,the most suitable water regime to produce tomato during the summer seasons was $80 \%$. The same results could be obtained using 100, and $120 \%$ from class A pan, but without any significant difference. So, it's recommended to use the less water regime to save water. Finally, the best vegetative growth obtained when $73 \%$ shading density interacted with any water regime without any significant differences between them, so, it's recommended to use the shading with $73 \%$ density as well as $80 \%$ water regimes

\section{References}

Abdul Mateen ; K. A. Salama and K. Nawab. 2007. Response.of exotic tomato lined to different light intensities. Sarhad J.Agric.. 23, (4):927-932.
Adam, S. F; A, M. Abdalla and A. F. Abou-Hadid. 2002. Effect of shading on the growth and productivity of some tomato cultivars in the summer season. Egypt. J. Hort. 29 (2): 271- 280.

ADAS/MAFF, 1987. The Analysis of Agricultural Material Book, 427.3rd Edition HMSO. London

Ali, F.S.M 2010. Effect of shading, salinity and bacterial inoculation on productivity and quality of sweet pepper under protected cultivation. Ph.D Thesis, Ain Shams University.

A.O.A.C. 1990. Association of Official Analytical Chemist official methods of analysis, 15th Ed.; Inc. Arlington, Virginia 22201, USA.

Bartzanas, T. and C. Kittas. 2006. Influence of vent design on greenhouse microclimate during dehumidification with simultaneous heating and ventilation. Acta Hort. 719: 349-355.

Bushra Bibi,M.Sajid;A. Rab, S. T. Shah, N. Ali, I. Jan, I. Haq, F.Wahid, B. Haleema and I. Ali .2012 Effect of partial shade on growth and yield of tomato cultivars. g.j. b.a.h.s.1(1):22-26. 
Byari. S.H. and A.R. Al sayed 1999. The influence of differential irrigation regimes on five green house tomato cultivars: I.the influence of differential irrigation regimes on vegetative growth. Egypt. J. Hort. 26, ( 2), ..109-125

Coelho, M., F. Baptista, V. Fitas da Cruz and J. L. Garcia. 2006. Comparison of four natural ventilation systems in a mediterranean greenhouse. Acta Hort. 719: 157-164

De Groot CC, Marcelis LFM, Van den Boogaard R, Lambers H (2002) Interactive effects of nitrogen and irradiance on growth and partitioning of dry mass and nitrogen in young tomato plants Functional Plant Biology 29: 13191328

El-Aidy,F.S. Moustafa and M.ElAfry.1983.Influence of shade on growth and yield of

tomatoes cultivated during the summer season in Egypt. Plasticulture47(3), 2-6

El-Abd, M. T. G., S. A. Shanan, A. F. abou- Hadid and M. M.Saleh. 1994. Effect of different shading densities on growth, yield of tomato and Elcucumber plants. Egypt. J. Hort., 21 : 65-80.

Beltagy,A.S.,S.M.Taha,S.M.Hassan,H.M.Gom aa.and M.A.Msksoud. 1984. Effect of different water regimes on tomato 1-growth, yield and fruit quality.Annals Agric.

Sci.Ain shams Univ. 29(2) 937-956.

El-Gizawy, A. M., H. M. Gomaa, K. M. ElHabbasha and S. S. Mohamed. 1992 Effect of different shading levels on tomato plants: 1.Growth, flowering and chemical composition. Acta Hort. 323: 341- 347.

El-Sayed, I. I. S. 2009. Effect of some shading and ventilation treatments on tomato plants grown in perlit culture. Ph. D. Thesis, Fac. Agric., Ain Shams University, Egypt.

El-Sawy,A.M., M. M. Wadid, U. A. El-Behairy, G. Zocchi and A. F. Abou-

Hadid.2011. Response of strawberry plants shortening day length, shading and cold storage under egyptian conditions. Egypt.J.Agric.Res.,89(2) (673-686).

El-Kassas,A.I. 1985. Studies on the production of cucumber in the summer season. M. Sc. Thesis,Fac. Agric., Kafr El- Sheikh,Tanta University.

FAO. 1977. Guidelines for predicting crop water requirements. Irrigation and drainage paper, 24, FAO, Rome

Fattahallah, M.A. 1992. Response of tomato to various irrigation regimes in relation to farmyard manure fertilization II yield fruit quality. Menofiya J. Agric. Res., 17 No. (3): 1327- 1351.

Gent, M. P. N. 2005. Effect of shading on yield and composition of fruit and leaves of greenhouse tomato. HortScience. 40: 993-1147.
Goma, H. M. 1966. Effect of shading, pruning ,staking and plant population on the growth and chemical contents of tomato plants. Ph. D. Thesis, Fac. Agric., Ain Shams University.

Hamamoto, H. Y. Shishido, T. Uchiumi and H. Kumakura. 2000. Effects of low light intensity on growth, Photosynthesis and distribution of photo assimilates in tomato plants. Environment Control in Biology. 38 (2): 63-69.

Hasni, A., B. Draoui, F. Bounaama, M. Tamali and T. Boulard. 2006. Evolutionary algorithms in the optimization of natural ventilation parameters in a greenhouse with continuous roof vents. Acta Hort. 719: 49-55.

Ibrahim.A.A.2005. physiological studies on yield and quality of tomato PhD. Sc. Thesis, Fac. Agric., Benha University, Egypt.

Merghany,M.M. 1997. Effect of irrigation system and nitrogen level on vegetative growth, yield componenents and some chemical composition of tomato plants grown in newly reclaimed sandy soils.Ann.Agric. Sci. Moshtohor. 35(2): 965- 981 .

Moustafa, S. M. S. 1991. Effect of shading on growth, yield and fruit quality of tomato plant. M. Sc. Thesis, Fac. Agric., Ain Shams University, Egypt.

Nahar.K, and R. Gretzmzcher 2002. Effect of water stress on nutrient uptake, yield and quality of tomato ( Lycopersicon esculentum Mill.) under subtropical conditions. Die Bodenkultur 53(1).

Navarrete, M. and B. Jeannequin.2000. Effect if frequency of axillary bud pruning on vegetative growth and fruit yield in greenhouse tomato crops. Scienta- Horti. 86 (3) 197-210

Liu, X. Z., S. Z. Kang and J. H. Zhang. 2002. Yield and photosynthetic responses of tomato (Lycopersicon esculentum) to shading at different growth stages. Indian Journal of Agricultural Sciences. 72 (2): 106-108.

Liu,X., Z, S. Qing, K. Shaozhong and L. Qingzhi.2003. Effects of shading on nitrogen in tomato plants at different growth stages .Chinese Journal of Applied and Environmental Biology. 2003-05.

Locascio, S. J. and A.G. Smajstrla. 1996. Water application scheduling by pan evaporation for drip irrigated tomato. J. Amer.Soc. Hort. Sci. 121:63-68

Locascio, S. J., Olson, S. M., Rhoads, F. M., C. D. Stanley and A. Csizinszkg, 1986. Water and fertilizer timing for trickle- irrigated tomatoes. Proceeding of the Florida state Hort Soc., 98,237239.(Cf.Hort.Abstr.,57,5:3454)

Sibomana.I. C, J.N. Aguyoh and A.M. Opiyo. 2013. Water stress affects growth and yield of container grown tomato (lycopersicon esculentum mill) plants.G.J.B.B.,vol.2(4):461- 466 
Snedecor, G. M. and W. G. Cochran. 1980. Statistical methods, Sixth Edition, Lowa State Univ. Press, Amer. Lowa, USA

Teitel, M., M. Barak, J. Tanny, S. Cohen and Y. Zhao. 2008. A comparison between the effects of ventilation and evaporative cooling on greenhouse air and crop temperatures. Acta Hort. 797: 580-598.

Watanabe, F. S. and S. R. Olsen. 1965. Test of an ascorbic acid method for determining phosphorus in water and $\mathrm{NaHCO} 3$ extracts from soil. Soil Sci. Soc. Am. Proc. 29: 677- 678 . 


\section{تاثير بعض العوامل المناخية والرى على النمو والمحتوى الكميائى للطماطم}

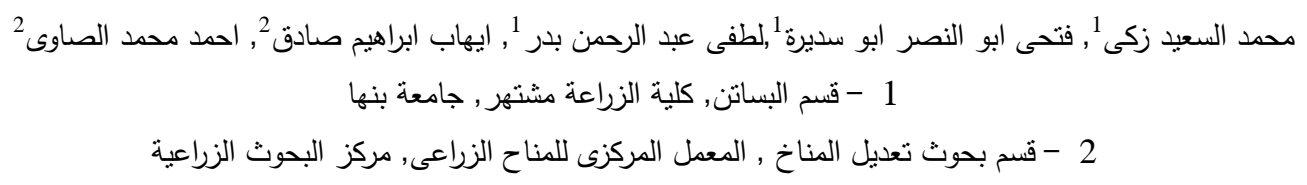

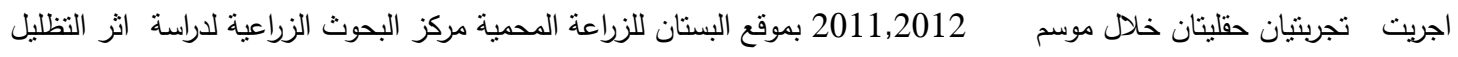

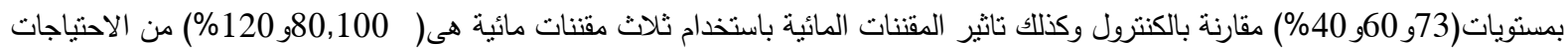

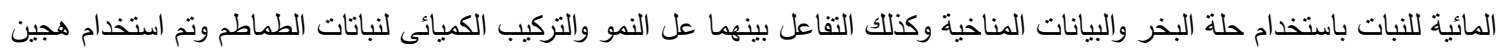

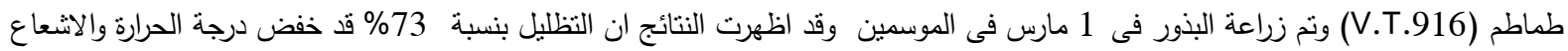

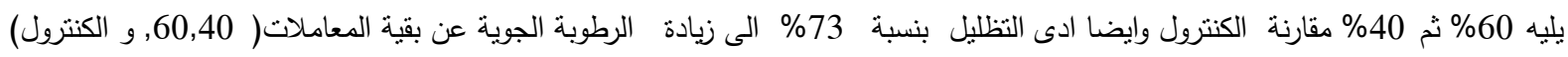

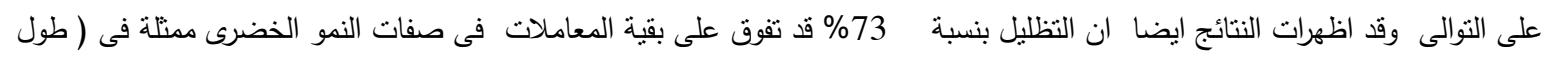

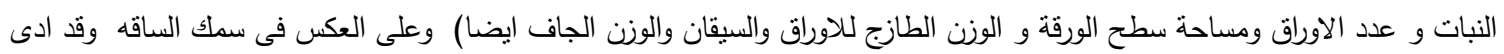

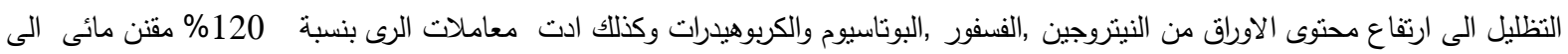

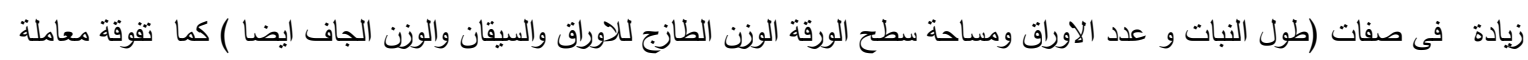
الرى بنسبة 120\% مقنن مائى فى زيادة محتوى الاوراق من الفسفور والبوتاسيوم فى الموسم الثانى فقط ) ومحتوى الكربوهيدرات خلال

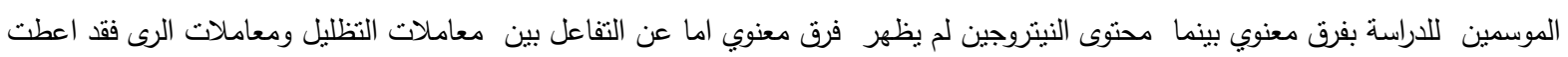

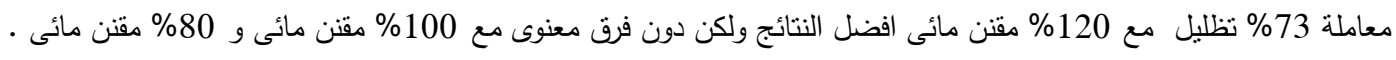

